\title{
Pharmacognostic Evaluation on Seeds of Madhuca longifolia (Koen.) Macbr. Var. Iatifolia (Roxb.) A. Cheval
}

\author{
Bindu Gopalkrishnan* and CL. Ringmichon \\ Department of Botany, Mithibai College, Affiliated to University of Mumbai, Vile Parle (W), Mumbai-56, India.
}

\begin{abstract}
Introduction: Mahuwa i.e., Madhuca longifolia (Koen.) Macbr. Var. latifolia (Roxb) A. Cheval belongs to family Sapotaceae. The local people and aboriginals use the oil extracted from the seeds for cooking purposes. The powdered seed has several therapeutic uses too. Recently seed oil is used as biodiesel. Although seeds and oil are in use; deliberate attempt to study them has lacked. Methods: Pharmacognosy can be the first step in deciding the status of a plant organ as a crude medicine. Hence comprehensive Pharmacognosy of Mahuwa seed was carried out by macroscopy, microscopy, histochemistry, powder study, proximate analysis and preliminary phytochemical studies. Results: The present study provides the microscopic diagnostic characters such as presence of sclerides, oil ducts, crystals etc in seed. Physicochemical studies revealed total ash $(0.65 \%)$, acid insoluble ash $(0.5 \%)$, water soluble ash (5.95\%), alcohol soluble extractive $(23.04 \%)$ water soluble extractive $(17.76 \%)$ and chloroform extractive
\end{abstract}

(12.3\%). Histochemistry and Preliminary phytochemical screening revealed the presence of saponnins, terpenoids, anthraquinone glycoside, cardiac glycoside etc. Conclusion: These studies will help in establishing the pharmacopeial standards for the said drug.

Key words: Pharmacognosy, Mahuwa, Sapotaceae, Seeds, Histochemistry, Phytochemistry.

Address for Correspondence:

Dr. Bindu Gopalkrishnan, Assistant Professor, Department of Botany, Mithibai College, Affiliated to University of Mumbai, Vile Parle (W), Mumbai-56, India.

Phone no: 09892391428

E-mail: bindu_phd@rediffmail.com

DOI : 10.5530/pj.2016.1.8

\section{INTRODUCTION}

In the present scenario, there is a great deal of interest in herbal medicine throughout the world.Hence it is necessary to identify and characterize the crude drugs well before the use. This can be easily and reliably done by the Pharmacognostic study. Pharmacognosy is the simultaneous application of various scientific disciplines with the object of acquiring knowledge of drugs from every point of view. Madhuca longifolia (Koen.) Macbr. Var. latifolia (Roxb) A. Cheval a tall tree commonly known as "Mahuwa. ${ }^{1}$ It is a tall deciduous tree with milky latex. Leaves are clustered near the ends of the branches, stipulate, elliptic to obovate, tomentose, when young deeply pink in colour, glabrous, base rounded or acute. Flowers in dense fascicles near the ends of the branches. Calyx with 4 sepals arranged in 2 whorls. Corolla cream coloured, twice as many as sepals. Stamens 20-24, staminodes zero. Ovary hirsute, hairy at the base, style 1 . Fruit berry. ${ }^{1}$ (Figure 1) The fruit is edible and medicinally important for curing many ailments. Seeds are used in the treatment of chronic rheumatism, headache, piles, constipation, haemorrhoids, oedema, spermicidal activity etc. ${ }^{2-4}$ The present study is therefore, intended to bring the salient; morphological characters of these seeds so as to lay down the standards which are of utmost important to authentify a crude drug.

\section{MATERIAL AND METHODS}

\section{Collection of Plant material}

Authentic seed samples were collected from Murbad in Maharashtra, India. The sample was authenticated for its botanical identity from the standard herbaria at Blatter herbaria (Mumbai). The accession no. of the sample is (ACC. No 36504). A voucher specimen has been deposited in Botany Research Laboratory of K. V. Pendharkar College, Thane, Maharashtra, India. After collection some of the seeds were preserved in FAA solution. Remaining seeds were dried and made into powder.

\section{Pharmacognostic Studies}

Pharmacognosy of the seed was carried out using standard methodology.

\section{(a)Macroscopy:}

The seeds were studied for its morphological characters using appropriate techniques. $^{5}$

\section{(b) Microscopy}

Transverse hand cut sections were taken and made permanent with suitable stains. ${ }^{910}$ Quantification and photomicrographs were taken of the permanent preparations. The cell contents were measured using stage and occular micrometer. ${ }^{6-8}$

\section{(c) Histochemistry}

The histochemical studies for the cell content were done by staining the hand cut sections with different reagents. ${ }^{9}$

\section{(d) Powder study}

The dried seed powder was treated with chloral hydrate solution followed by staining in 1\% saffranin for 5-10 minutes and mounted in $50 \%$ glycerine. ${ }^{10}$

\section{(e)Proximate analysis}

The physicochemical parameters like ash values (total ash, water soluble ash and acid insoluble ash) and extractive values (water, alcohol, chloroform extractives) were established using powdered drug. ${ }^{11}$

\section{(f)Fluorescence analysis}

The fluorescence response of powdered drugs exposed to U. V. radiations was studied. ${ }^{12,13}$

\section{(g) Preliminary phytochemical screening}

A known quantity of dried powder was extracted with chloroform, alcohol and water. These extracts were tested for different constituents. ${ }^{14-17}$

\section{RESULTS}

\section{Macroscopy}

The fruit is a berry usually one seeded, rarely with two seeds. Seed is exalbuminous and exarillate. It is compressed, ovoid to ellipsoid in 


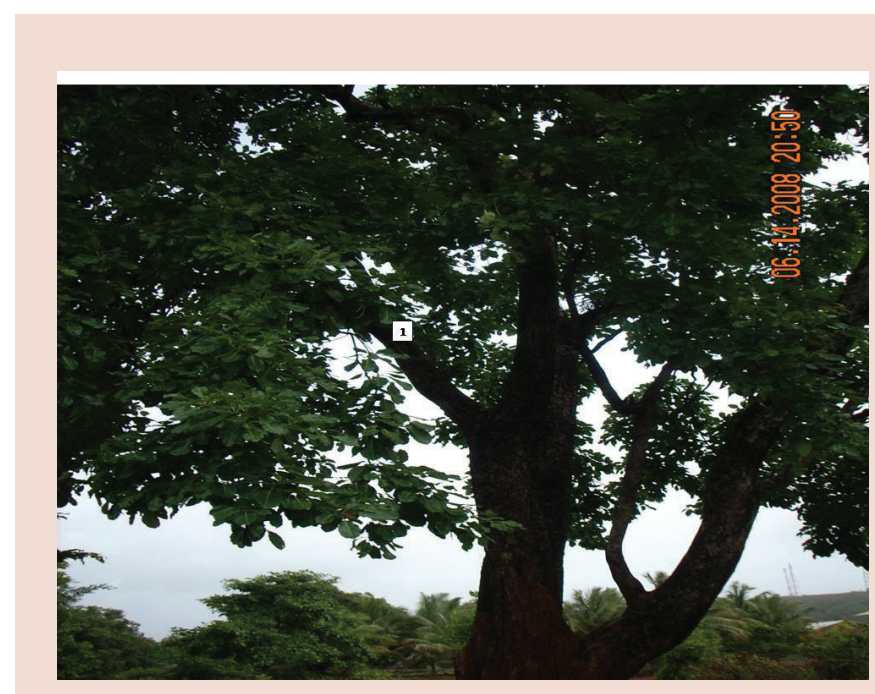

Figure 1: Mahuwa tree habit

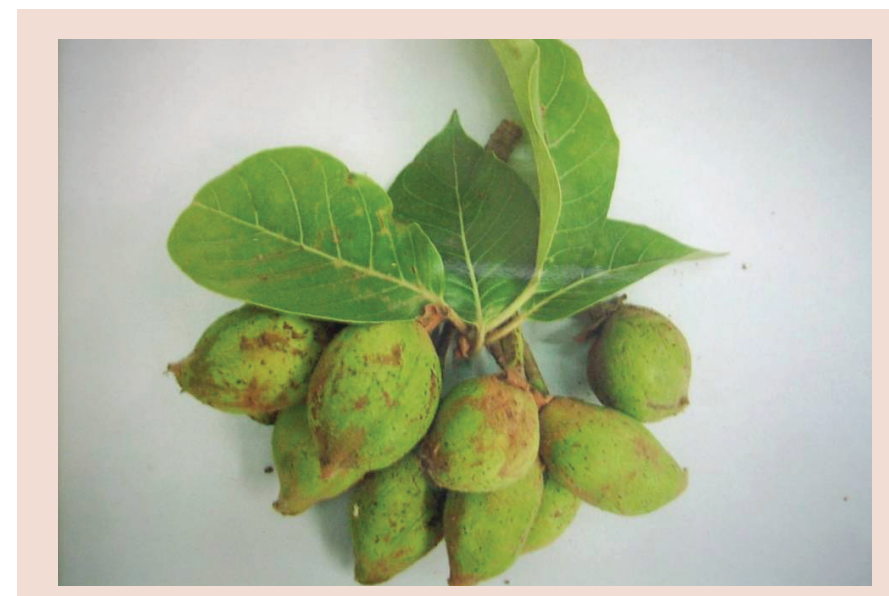

Figure 2: Fruit of Mahuwa

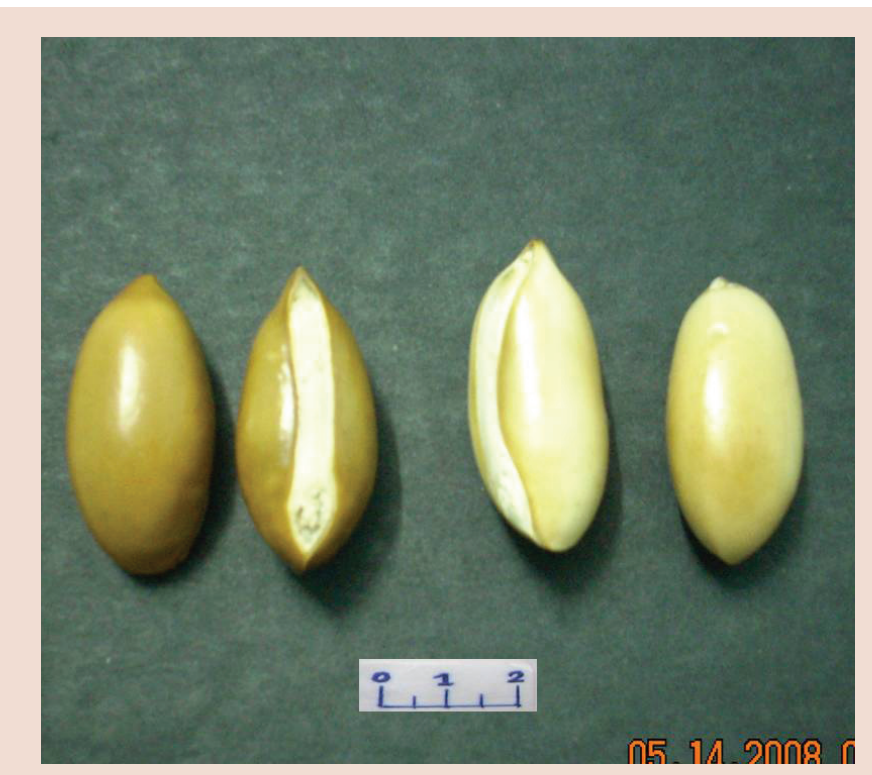

Figure 3: Seeds of Mahuwa shape, brown colour, (3-4 mm x 4-5 mm). Hilum and raphe are laterally placed with a ridge on the other side. The testa is soft, light brown, shining and of $1 \mathrm{~mm}$ thickness. The tegmen is dark brown with impression of perisperm. Perisperm is thin layered, cream coloured with venation. Endosperm is absent. Each cotyledon is thick and fleshy 3-4 mm in length, impression of perisperm is seen on it, when freshly cut milky latex exudes out. It possess characteristic odour; bitter and astringent taste (Figures 2-3).

\section{MICROSCOPY}

\section{T. S of Mahuwa seed shows the following parts}

The seed coat has two layers, an outer testa and inner tegmen. Testa is the outer part of the seed coat, with polygonal epidermal cells, followed by lignified sclerids. The sclerids are 4-6 layers with starch grains and oil globules. Next layer is the tegmen which is 2-3 layered dark brown, pigmented sclerenchymatous cells with vascular bundle. Nucellus is in the form of collapsed cells, leading to the formation of perisperm. Perisperm is thin layered. Endosperm is absent. Cotyledons shows outer and inner epidermis, followed by compactly arranged parenchymatous cells, gradually decreases on the lateral sides, poorly developed vascular bundles larger at the centre and smaller ones placed laterally.Oil globules and calcium oxalate crystals were observed (Figures 4-5).

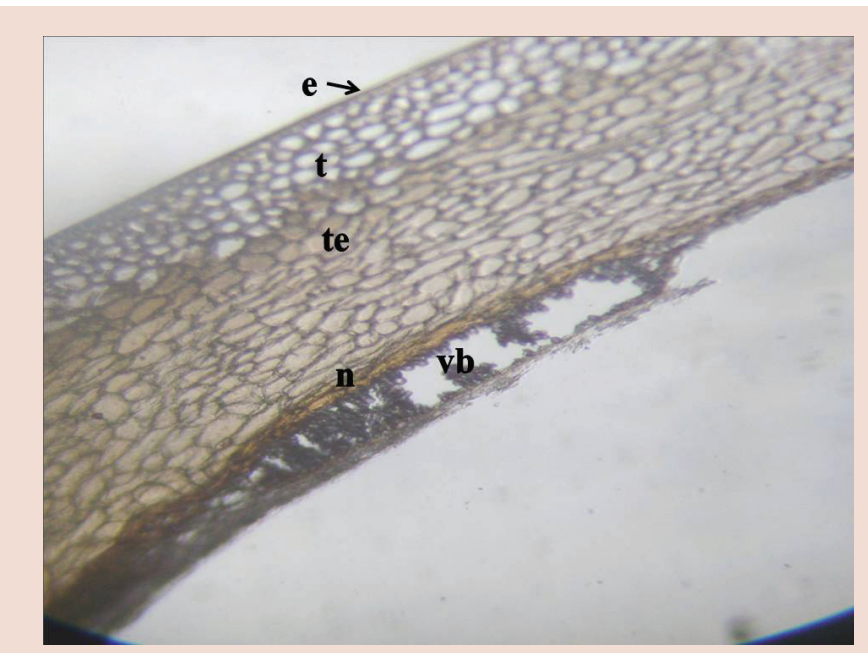

Figure 4: T.S. of seed showing regions of testa, tegmen and perisperm

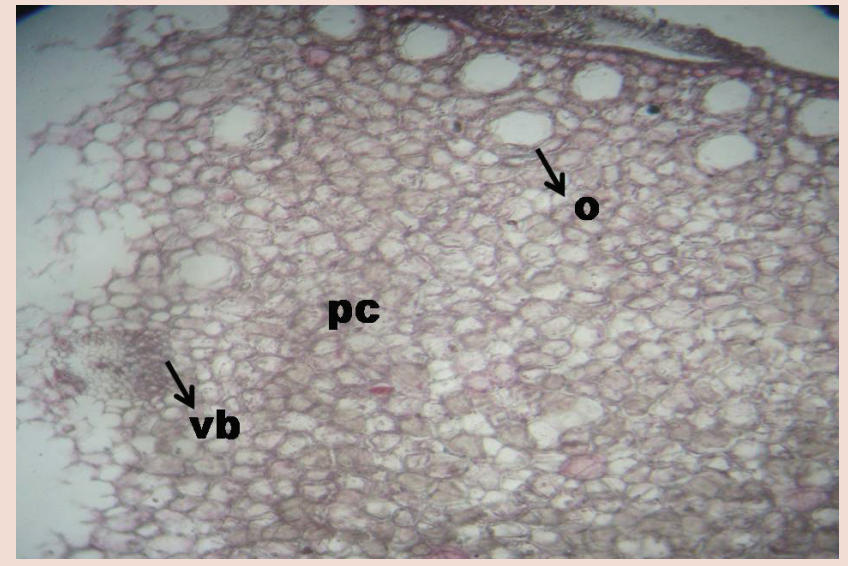

Figure 5: T.S. of seed showing region of cotyledon with oil ducts 


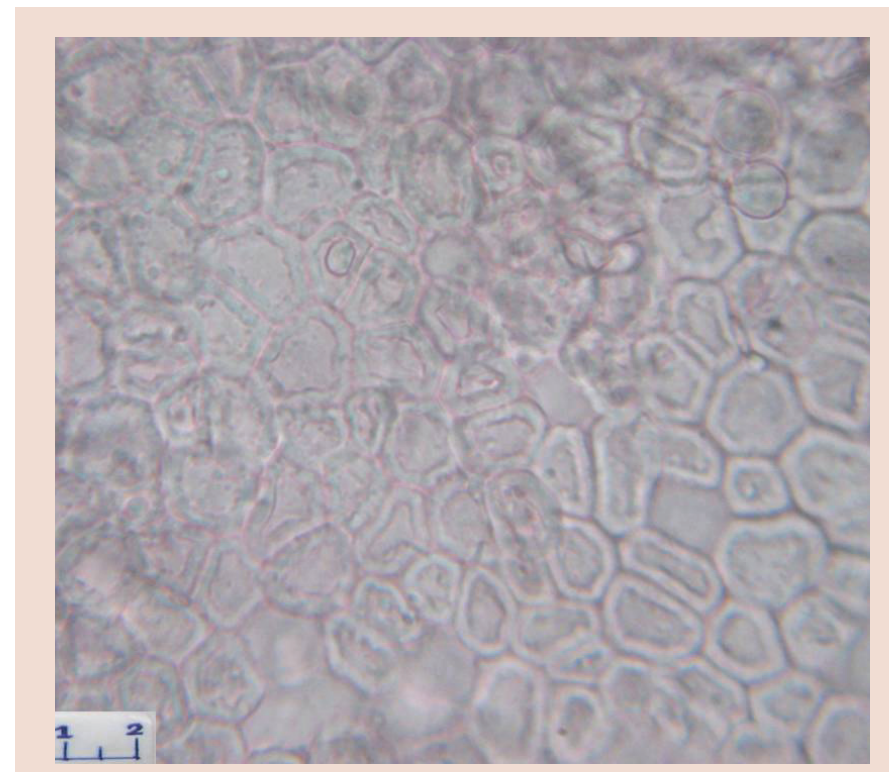

Figure 6: Cells of testa

\section{Powder study}

The seed powder on treatment with chloral hydrate solution followed by staining in $1 \%$ saffranin for 5-10 minutes and mounted in $50 \%$ glycerine exhibited fragments of sclerides (16.65-39.96 x $33.3 \mu \mathrm{m})$, Starch grains simple and compound type (3.2-6.6 $\mu \mathrm{m})$, cotyledon (parenchymatous) with oil globules (16.66-19.99-23.33-26.66 $\mu \mathrm{m})$, annular pitted vessels $(63.32-66.66 \times 6.66-9.99 \mu \mathrm{m})$, and nucellus $(6.65-6.66 \mu \mathrm{m})$ (Figures 6-9).

\section{Histochemical Analysis}

The Histochemical analysis using various reagents showed the presence of primary and secondary metabolites like starch, lipids, proteins, tannins, saponins, glucosides and mucilage respectively.

\section{Physicochemical evaluation}

The physicochemical constants such as ash values showed total ash $0.65 \%$, water soluble ash $5.95 \%$ and acid insoluble ash $0.5 \%$. Thus the acid insoluble ash value states the presence of least amount of silica in

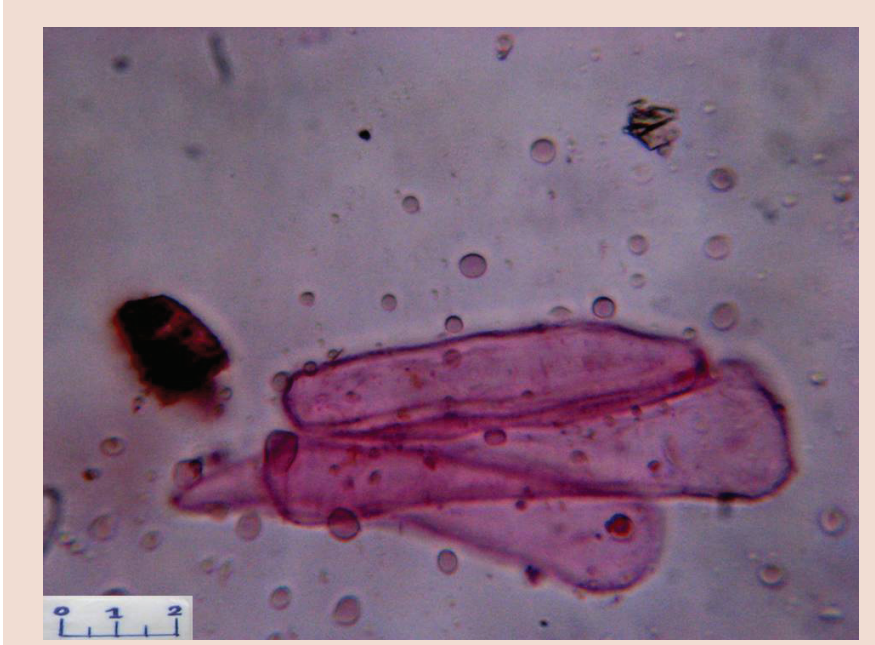

Figure 7: Oil globules and cells of tegmen

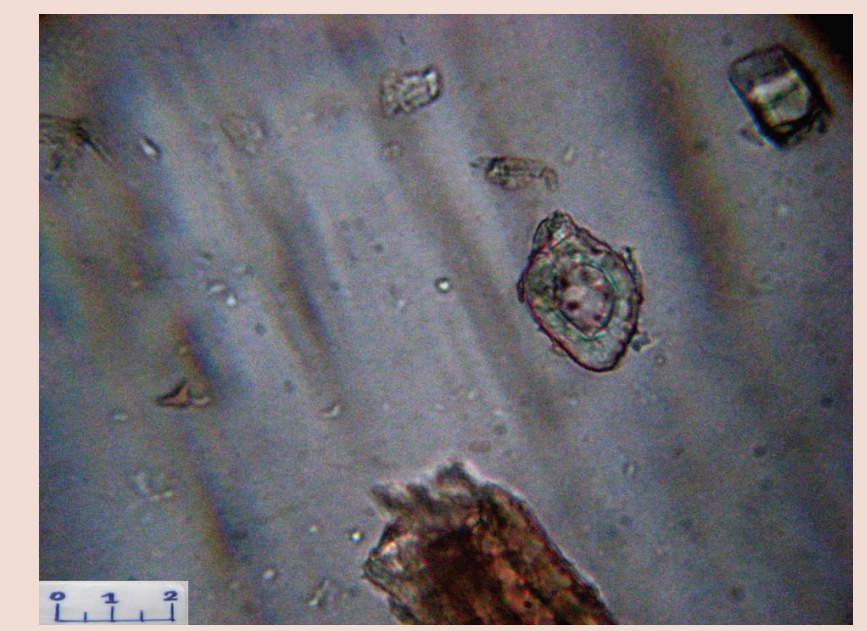

Figure 8: Scleride

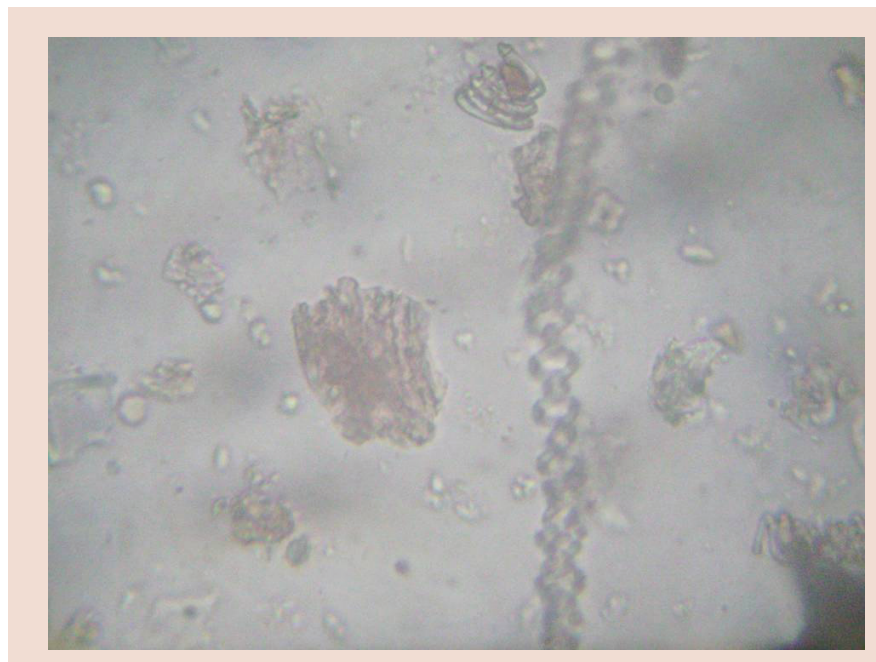

Figure 9: Vessels

seed powder. The extractive value of water is $17.76 \%$, ethanol $23.04 \%$ and chloroform $12.3 \%$. the above extractive values determine that more chemical constituents are soluble in the solvent ethanol.

\section{Fluorescence analysis}

The seed powder treated with different chemicals exhibited various colours in the UV light. The predominant colour was green in most of the test. The results are depicted in Table 1.

\section{Table1: Fluorescence analysis}

\begin{tabular}{cccccccccc}
\hline Test & i & ii & iii & iv & v & vi & vii & viii & ix \\
Fluorescence & $3 y G$ & gy & $2 G$ & $2 y G$ & $3 G$ & $1 G$ & $2 G$ & $3 G$ & $1 G$ \\
\hline
\end{tabular}

Keys to the letters and numbers used-

\begin{tabular}{lll} 
Predominant colours: & Modifying colours: & Quality of colours: \\
G- Green & y- Yellowish & 1 Very light \\
& g- greenish & 2 Light \\
& & 3 Dark \\
\hline
\end{tabular}




\section{Preliminary phytochemical studies}

The Preliminary phytochemical studies revealed the presence of terpenoids, anthraquinone glycoside, cardiac glycoside, saponin and tannins in water, ethanol and chloroform extracts Table 2.

Table 2: Preliminary phytochemical screening

\begin{tabular}{|c|c|c|c|}
\hline Test for phytoconstituents & $\begin{array}{l}\text { Water } \\
\text { extract }\end{array}$ & $\begin{array}{c}\text { Chloroform } \\
\text { extract }\end{array}$ & $\begin{array}{l}\text { Ethano } \\
\text { extract }\end{array}$ \\
\hline Test for Starch & + & + & + \\
\hline Test for Terpenoids & + & + & + \\
\hline Test for Proteins & + & + & + \\
\hline Test for Amino acid & + & + & + \\
\hline Test for Mucilage & + & + & + \\
\hline Test for Alkaloids & - & - & - \\
\hline Test for Anthraquinone glycoside & + & + & + \\
\hline Test for Cardiac glycoside & + & + & + \\
\hline Test for Saponin & + & + & + \\
\hline Test for Tannins & + & + & + \\
\hline Test for Steroids & - & - & - \\
\hline Test for Flavanoids & - & - & - \\
\hline
\end{tabular}

\section{DISCUSSION}

It was relevant to study the seed of Madhuca longifolia (Koen.) Macbr. Var. latifolia (Roxb) A. Cheval from pharmacognostical angle so as to prove its status as a herbal medicine. It was found that, morphological characters like colour, odour, taste etc are useful in gross identification. Microscopical characters such as sclerids in testa, collapsed cells of nucellus, absence of endosperm and presence of cotyledon etc. are of important to distinguish authentic drug from an adulterant or a substitute. Histochemical studies help to detect major chemical components like starch, lipids, proteins, tannins, saponins, glycosides and mucilage from the crude drug at primary level. Preliminary phytochemical screening gives confirmation to the results observed in histochemical studies as well as a general idea regarding the nature of chemical constituents of the seed. Powder study can be used in identification of authentic plant. The physicochemical parameters like ash values, extractive values, as well as the fluorescence analysis were put forth for the seed are beneficial for efficient assessment of authentic drug before use. The Pharmacognostical standards put forth can add valuable information about the plant. Detailed phytochemistry and pharmacological studies are in progress.

\section{ACKNOWLEDGEMENT}

The authors are thankful to the mentor Late Dr. Shraddha N. Shimpi for her guidance throughout for the completion of this research work.

\section{ABBREVIATION USED}

Var: variety, mm: millimeter, $\mu \mathrm{m}$ : micrometer, U.V.: Ultra violet.

Abb used in figures: e-epidermis, t-testa, te-tegmen, n-nucellar cells, o-oil duct, pc-parenchymatous cells of cotyledon, vb-vascular bundle.

\section{REFERENCES}

1. Almeida MR. Flora of Maharashtra. Orient Press, Mumbai 2001; A, pp. 169-70.

2. Anonymous. The Wealth of India, Raw Materials, Publication and Information Directorate, CSIR, New Delhi 1962; 6: pp. 298-301.

3. Kirtikar KR, Basu BD. Indian Medicinal Plants. Oriental enterprises; 2001. p. 2058-61.

4. Nadkarni KM. The Indian Materia Medica. Vol. I. Popular Prakashan; 1976.

5. Mukherjee PK. Quality Control of Herbal Drugs- An Approach to evaluation of Botanical: Business Horizons Pharmaceutical Publishers. New Delhi; 2002.

6. Khandelwal KR. Practical Pharmacognosy. Nirali prakshan; 2004.

7. Johanson DAO. Plant Micro technique. Mc. Grew Hill Book Co, New York; 1940.

8. Jackson BP, Snowdon DW. Atlas of Microscopy of Medicinal Plants. Culinary Herbs and Species. Stanley Thornes Publishers Ltd; 1990.

9. Krishnamurth KV. Methods in Plant Histochemistry S. Vishwanathan Private Ltd; 1988

10. Bindu G, Shimpi SN. Pharmacognostical studies on stem bark of Madhuca longifolia (Koen.) Macbr. Var. latifolia (Roxb) A. Cheval. I J Nat Prod Reso. 2012; 3(2): 232-6.

11. Anonymous. The Ayurvedic Pharmacopoeia of India, Government of India. Ministry of Health \& Family Welfare. The Controller of Publications, Civil Lines, New Delhi; 2006

12. Chase CR, Pratt R. Fluorescence of Powdered Vegetable Drugs with Particular Reference to Development of a System of Identification. J Amer Pharma Assoc (Sci.Ed.). 1949; 38(6): 324-33

13. Kokoski CJ, Kokoski RJ, Salma FJ. Fluorescence of Vegetable Powdered Drugs under Ultra-Violet Radiation. J Amer Pharma Assoc (Sci. Ed.). 1958; 107(10): 715-7.

14. Brain KR, Turner TD. Practical evaluation of Phyto pharmaceuticals. Wright Scientechnica Bristol; 1975.

15. Daniel M. Medicinal plants-Chemistry and Properties. Oxford and IBH, Publishing Co. Pvt. Ltd., Delhi; 2006.

16. Edeoga HO, Okwu DE, Mbaebie BO. Phytochemical Constituents of some Nigerian medicinal plants. Afri J Biotech. 2005; 4(7): 685-8.

17. Misra G, Mitra CR. Constituents of Fruit and Seed of Mimusops elengi. Phytochem. 1967; 6(453): 1909 


\section{PICTORIAL ABSTRACT}

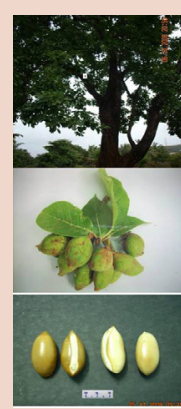

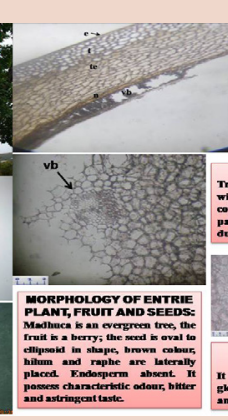

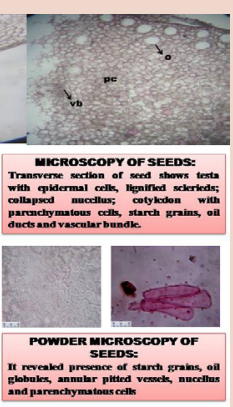

\section{SUMMARY}

- The Madhuca longifolia var. latifolia is a tall tree commonly known as Mahuwa.

- The fruit is edible as vegetable, the seed yield oil which is used in lighting lamps. This tree is well known among the aboriginals of Maharashtra.

- The seeds are used in treatment of chronic rheumatism, headache, piles, constipation and as spermicidal activity.

- Until now, no scientific investigation had been carried out for the standardization of Madhuca longifolia Macbr. Var. latifolia (Roxb.) A. Cheval seed. Hence it was felt necessary to put forth the pharmacopeial evidences of seed so that it can be a part of herbal world.

\section{ABOUT AUTHORS}

Dr. Bindu Gopalkrishnan: Is an Assistant Professor at Department of Botany, Mithibai College, Mumbai. She has published 17 research papers. Dr. Bindu has completed one BCUD research project funded by University of Mumbai. She is currently working on UGC Minor Research Project related to Pharmacognosy. Three Best paper awards were won by her during various paper presentations in conferences. Her area of study is pharmacognosy, photochemistry, pharmacology and ethno medicine.

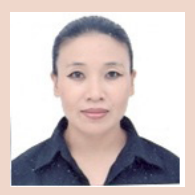

Dr. CL Ringmichon: Was working as a Senior Research Fellow (SRF) in Indian Council of Medical Research (ICMR), New Delhi. She has published 07 research papers. Currently she is working on ethno medicinal plants of Manipur. Her doctoral research focused on the Pharmacognostic and Pharmacological studies on some Ethnomedicinal Antipyretic Plants from Manipur. She has also received Rajiv Gandhi Scholarship for her Research work. 